\title{
Analysis of the Need for the Underwearules Program as a Sexual Education Service in the Prevention of Early Childhood Sexual Violence
}

\author{
Risty Justicia*, Mirawati, Wigati Nurfadilah Soeparman, Neng Sri Sinta Asih, Endah Permata Sari \\ Universitas Pendidikan Indonesia \\ Bandung, Indonesia \\ *risty@upi.edu
}

\begin{abstract}
This research is based on the problem of early childhood sexual violence which cases continue to increase every year. The purpose of this study is to determine the analysis of needs in the development of the Underwear Rules program as a sexual education service and sexual violence prevention efforts that can reach ages 4 to 6 years. This research uses mixed methods design with embedded mixed methods. This program is expected to identify the constraints and needs in implementing sex education service programs for early childhood. In addition, the birth of this program will make a positive contribution to the science of child education, especially early childhood sex education.
\end{abstract}

Keywords—sex education, early childhood, underwear rules

\section{INTRODUCTION}

KPAI (Child Protection Commission) revealed that in 2011 there were 2509 reports of violence, of which $59 \%$ were sexual violence which then increased in 2012 where there were 2637 reports, $62 \%$ of which were sexual violence [1]. Cases of violence against early childhood reported in 2015 were recorded in 1975 and increased to 6,820 in 2016 (president Jokowi). Meanwhile, according to data from the witness and victim protection agency (LPSK) in 2019, there were 350 cases of sexual violence against children. At the beginning of 2020, a number of cases of sexual violence against children were still sticking out. Among them, cases of sexual harassment among 12 elementary school students in Seyegan sub-district, Sleman, Yogyakarta by teachers. KPAI noted, there were 17 cases of sexual violence in educational settings with 89 children victims, consisting of 55 girls and 34 boys.

The above problems show that early childhood knowledge about sex education is low. Children should be given an understanding from an early age, to protect themselves from deviations in attitudes and treatment of others that lead to sexual crimes. One of the importance of sex education in early childhood is that children can know the good touch and bad touch that other people do to them $[2,3]$. Therefore, the role of those closest to the child is needed to be able to provide understanding in early childhood sex education. One of them is from the child's closest environment, namely parents.
Basically, parents still tend to be embarrassed when they have to provide an understanding of sex education to their children [4]. Therefore, we need a way so that parents can provide sex education in accordance with the stages of early childhood development. One of them is by using a scanned picture card media and then entering a blog containing animation, songs and stories related to early childhood sexual education. Research on the use of learning media to introduce sex education to children has been tested using pictorial media, the results of the study prove that there are differences in the understanding of students' sex education between before and after being given image media information services [5].

As we have seen, sexual education is very important, especially for early childhood. But at the age of children, the explanation of sexual education requires something different, this is because the understanding of children is different from adolescents or adults. An effective creative media is needed to help children understand sexual education according to their age.

Sex education is a process by which people obtain needed information and knowledge about sex and sexual identity and forms of attitudes, beliefs and values [6] Sexual behavior such as touching one's own sexual organs, asking about differences between girls and boys, and playing doctor games quite often occurs in children before the age of 6 years [7]. The preschool years in early childhood are one of the most important years of children's life. In this period, children discover and explore their own or others' sexual development and desires [8]. The results of the research by Ochiogu et al [9] state that it is very important to introduce sex education much earlier, namely early childhood, because sex education will have a greater positive impact if it is given as early as possible.

The objectives that need to be known in sex education according to Roqib [10] mention several objectives as follows: (1) explaining children on biological topics such as puberty, (2) preventing children from violence, (3) preventing underage pregnancy, (4) preventing underage adolescents from having sex, (5) reducing cases of sex infection, (6) explaining the roles of men and women. 
Previous studies on sex education in early childhood have been carried out quite a lot, such as the views of parents [11], the involvement of parents in early childhood sex education [12].

\section{METHODS}

The research method used in this research is a mixed method with 80 participants who are kindergarten teachers in Bandung, Indonesia. Researchers distributed questionnaires via google form and researchers also conducted in-depth interviews with several kindergarten teachers in retrieving data.

\section{RESULTS AND DISCUSSION}

The provisional results in the research progress report in this first year include two things, namely the initial conditions or the underwearules service profile and the form of the underwearrules program as an effort to improve care for early childhood, the explanation is as follows:

\section{A. The initial condition of Underwearules service for early grade ECD children prior to the development of the Underwearules program.}

Data on the initial conditions of the underwearules program for kindergarten children was collected through distributing questionnaires to teachers. The number of samples taken was 80 educators spread across 8 (eight) Kindergartens, the details are shown in Table 1:

TABLE I. TOTAL DATA OF TEACHER RESPONDENTS

\begin{tabular}{|l|l|l|l|}
\hline No. & No. Name of School & \multicolumn{1}{c|}{ Level } & \multicolumn{1}{c|}{$\begin{array}{c}\text { Number of } \\
\text { Respondents }\end{array}$} \\
\hline 1 & TK Daarut Tauhid & Kinderganten & 10 Respondents \\
\hline 2 & TK At Taqwa & Kinderganten & 10 Respondents \\
\hline 3 & TK At Taufiq & Kinderganten & 10 Respondents \\
\hline 4 & TK Mutiara Alam & Kinderganten & 10 Respondents \\
\hline 5 & TK Nasywa & Kinderganten & 10 Respondents \\
\hline 6 & TK Al Fitroh & Kinderganten & 10 Respondents \\
\hline 7 & TK Armia & Kinderganten & 10 Respondents \\
\hline 8 & TK Sarijadi & Kinderganten & 10 Respondents \\
\hline Total & & 80 Respondents \\
\hline
\end{tabular}

The questionnaire given to the respondents contained a number of statements / questions to the teacher regarding the condition of sexual education services that children received at school, as well as the teacher's views regarding these services, especially for early childhood in Kindergarten (TK). An overview of the respondents and the results of the initial condition data based on the questionnaire that has been given are as follows:

\section{1) Overview of respondents}

Respondents who gave answers to questionnaires related to the Underwearules program for early childhood in kindergarten were students' early childhood education teachers. Based on the data collected, respondents consisted of 79 women or $99.5 \%$ and 1 man or $0.5 \%$ men. Respondents also had various ages, namely 20 people aged less than 30 years, 35 people aged 30 35 years, 15 people aged 35-40 years, 10 people who were over 40 years old and none were over 64 years old. This illustrates that all respondents who gave answers to the research questionnaire were of productive age, where 47 or $59 \%$ of them were teachers who worked from 07.15-14.30. An overview of respondents can be seen in Figure 1:

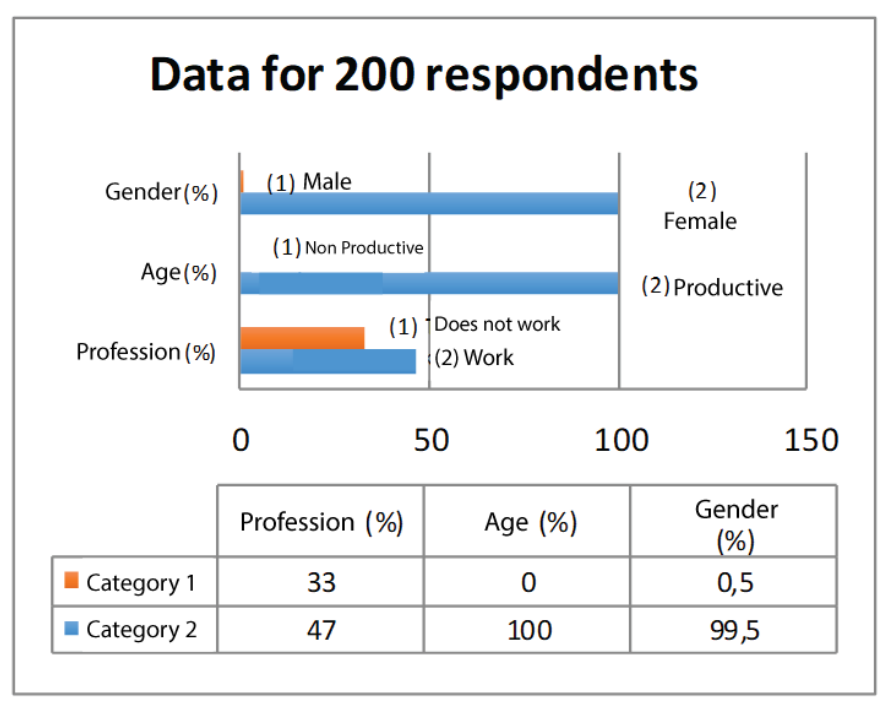

Fig. 1. Overview of respondents.

Based on Figure 1, it can be seen that in general the majority of early childhood teachers who are respondents are women who are of productive age and have jobs.

2) Teachers' understanding of early childhood sexual education

a) The importance of early childhood sex education: On questions related to the material about the importance of early childhood sexual education, all respondents generally answered that sex education is something that needs to be given from an early age. The time for general health checks based on respondents' answers is carried out regularly once every three months as many as $6.5 \%$ (13 people), once a semester as many as $53.5 \%$ (107 people) and once a year as many as $40 \%$ ( 80 people) (see figure 2 ). 


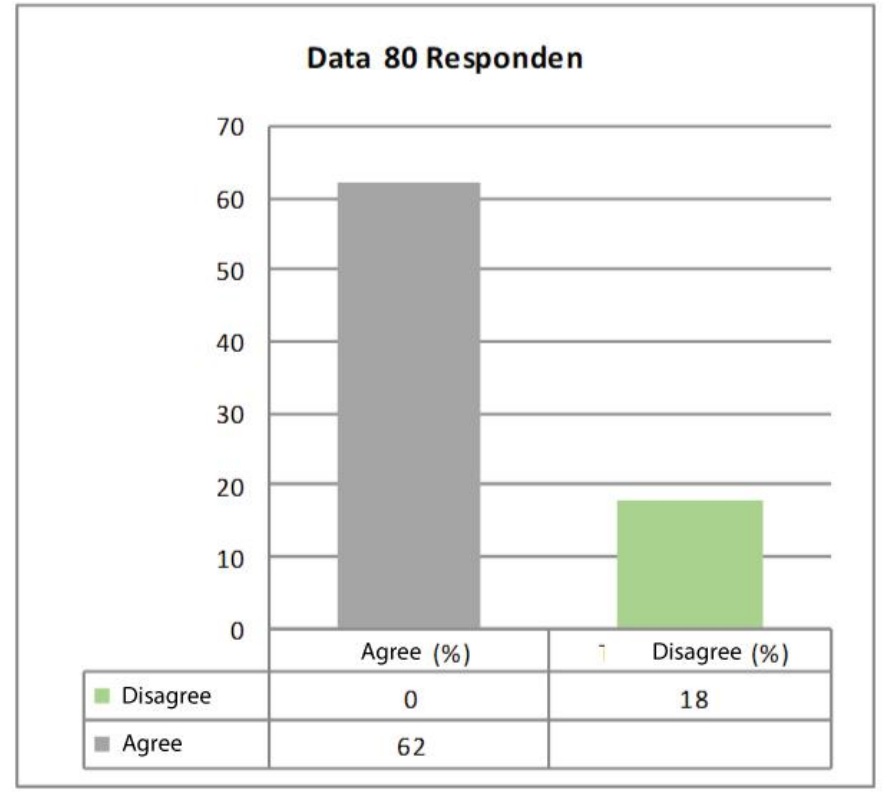

Fig. 2. Description of parents' understanding of the rise of sexual violence cases based on respondents' answers.

b) Early childhood sex education material: In the aspect of early childhood sex education material, most of the respondents answered that they did not know or that the school did not know about early childhood sex education. The data on respondents' answers related to this sex education material can be summarized in Table 2:

TABLE II. RESPONDENTS' ANSWER DATA RELATED TO EARLY CHILDHOOD SEX EDUCATION MATERIAL

\begin{tabular}{|l|l|l|l|}
\hline \multirow{2}{*}{ No } & \multicolumn{1}{|c|}{ Sex Education Materials } & \multicolumn{2}{c|}{ Respondents' Answers } \\
\cline { 3 - 4 } & & \multicolumn{1}{c|}{ Yes } & \multicolumn{1}{c|}{ No } \\
\hline 1 & Introduction of the Body & 57 & 143 \\
\hline 2 & Good touch and not good touch & 0 & 200 \\
\hline 3 & Good secrets and bad secrets & 29 & 171 \\
\hline 4 & $\begin{array}{l}\text { How to report to adults when } \\
\text { sexual violence occurs }\end{array}$ & 2 & 198 \\
\hline
\end{tabular}

The percentage of data on child sex education material based on the respondents' answers can be seen in Figure 3:

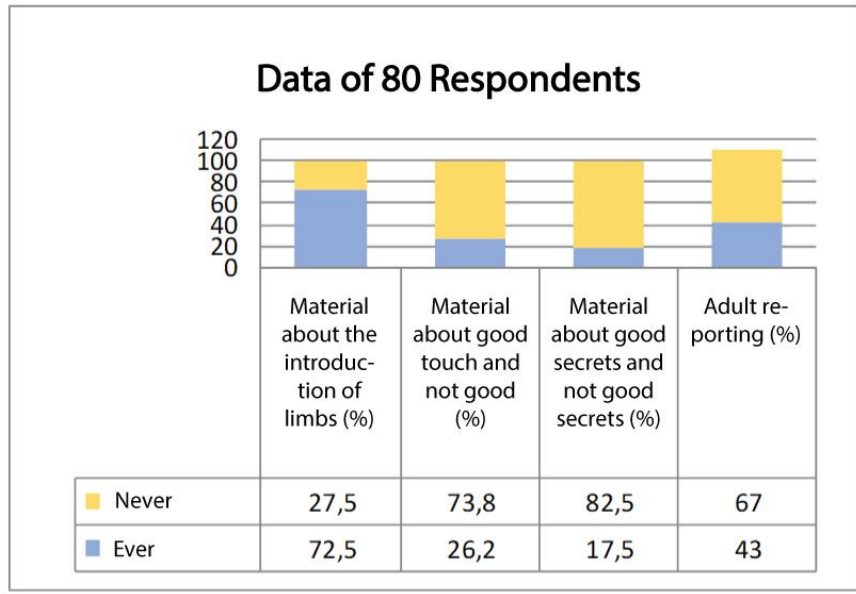

Fig. 3. Description of early childhood sex education materials.

There is something interesting about the participants reporting that teachers rarely provide sex education materials about good touch and bad touch and reporting to parents, including material rarely provided by teachers in early childhood. This is the same as research that took place in Hong Kong, the results showed the highest level of confidence in teaching about self-protection and the lowest level of confidence in teaching about body parts of both sexes and where the baby came from [13].

In addition, Walker and Milton [14] stated that in implementing sexuality education, teachers are often unsure about what to teach under a particular topic, how to talk to children about topics, and how to approach the topic. Therefore, teacher educators should reserve more time for discussions with pre-service teachers about the breadth and depth of sexuality. This shows that the analysis of teacher needs in the implementation of the afterschool program as a sexual education service in early childhood is indeed important to be assessed.

\section{CONCLUSION}

The results showed that most of the teachers had already provided sex education in early childhood. However, there is an interesting result that teachers still rarely provide early childhood sex education material in the form of good touch material and bad touch with adult seeking help material. This can be an illustration for further researchers to examine more deeply the provision of sex education training for early childhood educators

\section{ACKNOWLEDGMENT}

Thanks to SEAMEO CECCEP for funding this research and also to the participants who were willing to be involved in the research process of the underwearules program needs analysis in preventing violence in early childhood. 


\section{REFERENCES}

[1] R. Justicia, "Program Underwear Rulesuntuk Mencegah Kekerasan Seksual Pada Anak Usia Dini”. Jurnal Pendidikan Usia Dini, 9(2), pp. 217-232. 2015.

[2] L. Counterman and D. Kirkwood, "Understanding Healthy Sexuality Development in Young Children”, NAEYC. www.naeyc.org. 2013.

[3] D. Kirby, The Impact of Sex Education on The Sexual Behavior Young People, New York: United Nations, Department of Economic and Social Affairs. No 2011/12, hal. 1-19. 2011.

[4] A. Listiyana, "Peranan Ibu dalam mengenalkan pendidikan seks pada anak usia dini”. EGALITA. 2010.

[5] M. Damayanti, C.T. Anni, and H. Mugiarso, "Layanan informasi dengan media gambar untuk meningkatkan pemahaman sex edukation siswa”. Indonesian Journal of Guidance and Counseling: Theory and Application, 7(1). 2018.

[6] J. Martin, H. Riazi, A. Firoozi, and M. Nasiri, "A sex education program for teachers of preschool children: a quasi-experimental study in Iran". BMC Public Health, 20, 1-9. 2020.

[7] C. Birol and E. Gömeçli, "Effect of the counselling course on the attitude of the students of pre-school teaching towards the children's masturbation behaviour". Procedia-Social and Behavioral Sciences, 5, pp. 2366-2371. 2010.
[8] M. Kurtuncu, L.U. Akhan, I.M. Tanir, and H. Yildiz, The sexual development and education of preschool children: knowledge and opinions from doctors and nurses. Sexuality and disability, 33(2), pp. 207-221. 2015

[9] I.N. Ochiogu, J. Miettola, A.L. Ilika, and T. Vaskilampi, "Impact of timing of sex education on teenage pregnancy in Nigeria: Crosssectional survey of secondary school students". Journal of community health, 36(3), 375-380. 2011.

[10] M. Roqib, "Pendidikan seks pada anak usia dini". INSANIA: Jurnal Pemikiran Alternatif Kependidikan, 13(2), pp. 271-286. 2008.

[11] R. Justicia, "Pandangan Orang Tua Terkait Pendidikan Seks Untuk Anak Usia Dini”. Early Childhood: Jurnal Pendidikan, 1(2), 28-37. 2017.

[12] N.M. Pratiwi, Keterlibatan Orangtua Dalam Pendidikan Agama Pada Anak Usia Dini (Studi Kasus Keluarganelayan Di Desa Ujungalang Kecamatan Kampunglaut Kabupaten Cilacap) (Doctoral Dissertation, Unnes). 2019.

[13] S.K. Cheung, J.L.Y. Kwan, and K.Y.K. Yim, "Pre-service early childhood teachers' perceptions about sexuality education and behavioural intentions towards children's curiosity about sexuality". Journal of Education for Teaching, 1-15. 2020.

[14] J. Walker and J. Milton, “Teachers' and Parents' Roles in the Sexuality Education of Primary School Children: A Comparison of Experiences in Leeds, UK and in Sydney, Australia." Sex Education 6 (4): pp. 415-428. 2006. 